\title{
Character Building of Early Young Learners through Gadget as Learning Media in Kindergarten
}

\author{
Endah Silawati, Setyaningsih Rachmania \\ PGPAUD, Universitas Pendidikan Indonesia, Kampus Cibiru Jl. Raya Cibiru, Bandung, Indonesia \\ Corresponding e-mail: endah_silawati@upi.edu
}

\begin{abstract}
This paper describes the use of gadgets as learning media in building children's characters in Indonesian kindergarten context. In this digital era, children can access many technologies easily, including using some gadgets. Most of the people believe that gadgets can only give negative effects to young children's character, but actually some studies proposed that when gadgets are used properly, they can give positive effects too. Due to the perception that gadgets are negative must be corrected because the use of gadgets can develop positive effects for the children depending on the programs created. The qualitative method employed in this study were observation and interview as well as data collection techniques. The students of TK Laboratorium UPI Kampus Cibiru were chosen as the research subjects. Gadgets that were used in this study were mobile phone, laptop and tablet/tab. The gadgets programs were selected based on the assumption of their positive effects for the children's characters. From the data gathered, it can be concluded that the use of gadgets is assumed effective as learning media in developing some children's characters. It is also recommended for kindergarten teachers to use gadgets as alternative learning media in class.
\end{abstract}

Keywords: $\quad$ character building, young children, learning media, kindergarten, ICT in early childhood education

\section{INTRODUCTION}

\subsection{Character Building in Early Childhood Education Context}

Character is psychological characteristics of someone's identity that differentiates one from another (Abidin, 2012). Positive character of someone is expected in every community because it deals with individual relationship among groups, conditions of civil society, and significant public issues. Positive character consists of knowing, desiring, and doing the good which produce habits of the mind, the heart, and action (Lickona, 1989). Moreover, there are three interrelated elements of character: moral knowing, moral feeling, and moral behavior (Lickona, 1989).

Some assumptions have been proposed that character is possible to be taught which is known as character education. It is an attempt to prepare individuals to make ethical judgments and to act on them (Howard; Berkowitz; Schaeffer, 2004). Character education is an important tool in preparing children to be a good citizen in the future. Its aim is to educate our children in judging and care deeply about what is right, and then do what they believe to be right in every events.

The history of character building is related with the history of education itself since the main purpose of education is character development of people. There are some approaches regarding building character, namely, traditional approach, developmental approach, caring approach and service learning (Lickona, 1989). In the beginning, traditional approach is done by putting character building in religion learning through drilling some dogmas. The second is developmental approach. It is the progressive movement of character building in the early $20^{\text {th }}$ century which states that the core of character education is not teaching children something "right and wrong," but teaching children to engage in critical thinking and to have a process in making decisions and actions. While the third is 
caring approach which stated that morality of care is relational rather than individual. It focused on primacy to moral emotions and sentiments that became the stimulus of moral action and moral reasoning which could not be justified universality (Howard; Berkowitz; Schaeffer, 2004).

Character building of early childhood might be done through modelling, habituation, and repetition in daily activities. In Indonesian kindergarten curriculum, the educational values for the characters which can be implanted for the early childhood (0-6 years), consist of four aspects, namely, 1) spiritual aspect, 2) personal/personality aspect, 3) social aspect, and 4) environmental aspect. Moreover, on the early childhood education the values that needed to be introduced and internalized in their behaviour consist of ; religious, honesty, discipline, tolerance and peace, self confidence, independent, helping others, working together, and collaboration, respect and politeness, responsibility, hard work, leadership and righteous, createve, humble, nature awareness and love for the nation (Dirjen PAUD, 2012).

Character is one of the developmental aspects that are critical to be developed in early years. There are many strategies in its development whether at home or at school which is called as character education. Some research showed that there are inter-related links between the successes of character education with the academic achievements along with the pro-social children behaviour, so that the atmosphere of the situation in kindergarten can be fun and conducive for the process of learning and teaching effectiveness (Dirjen PAUD, 2012). Other than that, the children who have good character are the ones that have matured emotion, high spirit and have the ability to manage stress which finally increases the physical health.

\subsection{ICT as Kindergarten Learning Media}

In this globalization era, the development of Information and Communication Technology (referred to ICT hereafter) has affected human life in every field, including in education field. This fact is noted by the increasing of educational technology policy in many countries (Roumell \& Salajan, 2016). Moreover, ICT also affects children's life. Nowadays, children have engaged with technology in their daily life (Hayes, 2006). One of the ICT devices that close to the children is gadgets. They perceive gadgets as small electronic devices which has particular function such as computer, laptop, mobile phones, camera, TV, tablet/ipad, MP, printer, handycam, netbook, X-box, e-reader (Silawati \& Rachmania, 2014)

Most of the people believe that gadgets can only give negative effect for the children such as television that lead to behaviour problems, attention disorder, aggression and obesity of the children (Jusoff \& Sahimi, 2009). Therefore some parents decide to dissociate children from gadgets since they believe that those technological devices can only bring negative characters for the children. They believe that by separating the children from gadgets will make the children have better character. But in fact, it is an unwise decision since, even though children do not play gadgets at home, it is possible that they will play it at other places, such as at internet cafes. This fact will bring worst effect to the children because children can access bad contents from the gadgets when they use it without parents' guide. This becomes a dilemma for most parents, teachers and caretakers.

On the contrary, if we use gadgets properly, it can give positive effect for the children. It can build technological literacy for children which is important to be comprehended in this $21^{\text {st }}$ century era (Blatchford \& Whitebread, 2003). Because of that, some studies have been conducted to develop friendly gadgets for children. One of the study conducted by Van Eck since 1999 concluded that digital games is possible to be used as learning media, because nowadays most of the learners are net generation who become digital natives and disengage with conventional instruction (Van Eck, 2006). It is commonly said as Digital Games based Learning (referred to DGBL hereafter). Moreover, Computer-based instructional games (referred to as CBIGs) are also assumed can be effective as learning media, especially for those who interact with computer games in early age (Butler, 2014).

Moreover, one of the study which proposes the effectiveness of gadget as learning media of children in developing some learning character such as enthusiasm and motivation for studying, determination for reaching high level achievement, independent and group learning, and linking and applying learning in new environments (Robertson \& Howells 2008). The use of gadgets as learning media is not only interesting for the children, but it would also be introducing technology to them in the positive ways.

From the study above it is shown that gadgets could be possible to be used as learning media at school since it can be give opportunities to the children to have playing activities, such as playing games through tablet, watching movies through 
television or listening music through MP3. In this case, those technologies provide playing activity which is the principal of early childhood education strategy (Dockett\&Fleer, 2002). Even though playing is not the only strategy for children to learn, but also for the children who have done quality play is more likely to have positive effort to be a successful learner (Curtis \& O'Hagan, 2003). In addition through playing, children explore and develop their potential (Suyanto, 2005). Other than that, it is possible to be used as learning media for other developmental aspects of the children including in building their character.

Based on assumptions above, this study investigates the using of gadget as learning media in building character of the children. The setting of the study is in Indonesian kindergarten.

\section{METHODOLOGY}

In gathering the data, some techniques were used such as observation and interview. Observation was conducted in investigating the learning process done by the teacher. While, interview was held by asking the children some open ended questions about the using of gadgets in learning activities. In addition the teacher was also asked about the process of learning development in interview session. All the data gathered were analyzed through writing out memo and coding techniques (Malik \& Hamid, 2016).

While in analyzing the data, qualitative approach with descriptive method was employed to describe the using of gadgets as learning media in developing childrens' characters.

This study took place at TK Laboratorium UPI Kampus Cibiru. The subject was a teacher with 15 students of Angklung class. It was assumed that all students had the same characteristics of age and developmental stages. The gender was not considered in this study.

Moreover, gadgets in this context were portable electronic devices which were selected namely laptops, mobile phones and tables. In this occasion those gadgets were used as learning media by taking the positive side for the children (Fine \&Thornbury, 2006),

Since the limitation of the time, this study only focused on building three children's character, namely, nature awareness, discipline and selfconfidence. Each character was developed through different gadgets which become the learning media at Kindergarten.

\section{FINDINGS AND DISCUSSION}

There are some stages in implementing the use of gadgets as language learning media in developing children's characters, namely: 1) developing learning planning, 2) implementing learning process, and 3) conducting learning evaluation. Character values were developed while children learn a language through gadgets, since learning in early childhood should be done holistically (Suyanto, 2005). This study focus on developing character of young children through gadgets in learning proses.

\subsection{Developing Learning Planning}

The first stage of this study is learning planning development using three learning themes, namely; 'the names of animals', 'the names of fruits', and 'numbers'. Learning planning is very important in arranging learning activities for children in order to ensure holistically of all developmental aspects in everyday activities through students' active involvement (Curtis \& O'Hagan, 2003).

Teacher had done some steps in developing learning plan, namely, 1) determining developmental stages in particular ages, 2) determining developmental and character indicators, 3) analysing learning materials, 4) determining learning themes, 5) arranging learning activities and 6) developing learning media. In this occasion, teacher used gadget as the learning media.

Teacher took three character values as the focus of developing which were; nature awareness, discipline and self-confidence. Then, after decided the character values and learning themes, the next step was the selecting of gadgets that will be used for each learning theme. Below is the list of learning theme, learning target and character values that were arranged in accordance with the selected gadgets:

Table 1. Lists of Learning Themes, Character Values and Gadgets' Program

\begin{tabular}{|c|c|c|c|}
\hline $\begin{array}{c}\text { Learning } \\
\text { Themes }\end{array}$ & $\begin{array}{c}\text { Gadget } \\
\text { Tools } \\
\end{array}$ & $\begin{array}{l}\text { Gadgets } \\
\text { Program } \\
\end{array}$ & $\begin{array}{c}\text { Character } \\
\text { Values }\end{array}$ \\
\hline $\begin{array}{l}\text { The names } \\
\text { of animals }\end{array}$ & Laptop & $\begin{array}{l}\text { Movie } \\
\text { animation }\end{array}$ & $\begin{array}{l}\text { Nature } \\
\text { awareness }\end{array}$ \\
\hline $\begin{array}{l}\text { The names } \\
\text { of fruits }\end{array}$ & $\begin{array}{l}\text { Tablet/ } \\
\text { Tab }\end{array}$ & Game & $\begin{array}{l}\text { Follow the } \\
\text { rules }\end{array}$ \\
\hline Numbers & MP4 & Song & $\begin{array}{l}\text { Self- } \\
\text { confidence }\end{array}$ \\
\hline
\end{tabular}

In the process of developing learning planning, teacher was interviewed to collect some data. From the interview conducted, it was found that in 
developing the learning plan, teachers faced some difficulties especially in analysing the suitable gadgets program for the children. To overcome this difficulty, teacher analysed some programs and asked the expert to judge whether or not those program are appropriate for the children.

\subsection{Implementing Learning Process}

The second stage was implementing the learning process. Several steps of activities were done. The initial step began with the activity for the children to watch video entitled 'Walking in the Junggle' through laptop. This first learning theme was 'the names of animals'. The next step was the main activity where the children were divided into three groups and did some movements according to the song. The last step was the closing activity where the children gathered together to retell the activities. In this activity, the children learn to love animal which is part of nature awareness character.

The second learning theme was 'the names of the fruits'. This activity used tablet/tab with the program of a game called Baby Bus. In implementing the program, several steps were done. The first step was opening session when children listened to the teacher's explanations of the learning activities and rules. Then, the second step was main activity when children were divided into three groups. Each group played the gadget orderly. They played this game until they got bored. Moreover, in third step, children discussed their learning experiences. In this activity, the children learned to get in line and follow the rules of the games that they played.

The third learning theme was 'numbers'. This activity used MP3 as learning media. The learning aim was to introduce number 1 to 10 through song that was played by MP3. There were several steps in this activity. The first step was opening activity when all children listen to a song entitle 'One Two Three' from MP3. Second step was the main activity when all children were asked to sing the song once more and then each student sing it in front of the class. The last step was closing activity when children discuss their learning experiences. Selfconfidence of the children was developed through this activity.

In investigating children perspective on learning activities, all children were interviewed. They were asked which gadgets program they liked most. From the data gathered, it showed that most children tend to like watching movie animation on laptop. The second position was playing game on tablet and the last position was singing the song through MP4.

\subsection{Conducting Learning Evaluation}

The last stage is evaluation process by using authentic assessment which defined as evaluation strategy in the context of ECE (Bagnato, 2007). Teacher observed children when they were involved in the learning activities using some check lists and making some memo. In learning activities, character values surfaced even with the various scales for each indicator. Other than that, the value of the character mostly surfaced because of the learning activities scenario. For example the 'follow the rules' character of the children surfaced when they qued to play games on the tablet. In this case, teachers' understanding of students' needs is essential factor in character building (Lewis, 2016).

Below is the analysis of children's character values which observed by the teacher.

Table 2. Evaluation of Children Character

\begin{tabular}{lc}
\hline \multicolumn{1}{c}{ Character Values } & $\begin{array}{c}\text { Percentage of } \\
\text { Improvement }\end{array}$ \\
\hline Nature awareness & $80 \%$ \\
Follow the rules & $83 \%$ \\
Self-confidence & $76 \%$ \\
\hline
\end{tabular}

The table shows that after following the learning activities there are some improvement of children character values. Children improve $80 \%$ in nature awareness, $83 \%$ on follow the rules and $76 \%$ on self-confidence. It can be concluded that the activities give positives effect to children character. In addition it is also important to consider children's perspectives on gadgets, therefore learning activities and students' needs will be suitable (Silawati \& Rachamania, 2014).

There are some limitations of this study since it only observed the character of children based on their behaviour while character of someone cannot be judged only by their behaviour (Howard; Berkowitz; Schaeffer, 2004). Moreover, learning process only used three kinds of gadget with three kinds of games program in short time of learning. The results from this study highlight the need for both researches in general and longitudinal research in particular. The character education Partnership, the largest and most inclusive of the organizations, is promoting more rigorous evaluation of character education programs and ICT for early children. 


\section{CONCLUSIONS}

In this era when the learners become digital natives, learning media should be considered to be changed from conventional to technological devices. The using of gadget is possible as learning media in building children character. Some stages should be done in this process, namely, 1) developing learning planning, 2) implementing learning process, and 3) conducting learning evaluation.

From the observation it can be concluded that by watching movie animation through laptops, playing games through tablets and singing a song through MP4s some character values was developed well.

Moreover it is recommended that in designing gadget as learning media, teachers should consider on children's perspectives on gadgets and their needs. Thus, more effective use of digital teaching to raise attainment happens when teachers are able to identify how digital tools and resources can be used to achieve improved learning outcomes, as well as having knowledge and understanding of the technology. This applies in all schools (Scottish Government, 2015).

\section{ACKNOWLEDGEMENTS}

This study was funded by UTU UPI in the program of Hibah Penelitian Dosen Muda, LPPM UPI year 2014. We are grateful to Prof. Dr. Hj. Mulyani Sumantri, M.Sc as the supervisor who has given generous guidance and support in conducting this study. We would also thanks to Eka Puji Lestari and Tsuraya Rachmatika who are the students of PG PAUD UPI Kampus Cibiru for their participation as teachers' model in gathering the data.

\section{REFERENCES}

Abidin, Y. (2012) Pembelajaran Bahasa Berbasis Pendidikan Karakter, Bandung: Refika Aditama

Bagnato, S., J. (2007) Authentic Assessment for Early Childhood Intervention, Best Practice. New York \& London: The Guilford Press.

Blatchford, J., S.\&Whitebread, D. (2003) Supporting ICT in the Early Years.Berkshire :Open University Press.

Butler, Y., G. (2014) The use of computer games as foreign language learning tasks for digital natives. System, XXX.1-12.

Curtis, A. \& O'Hagan, M. (2003) Care and Education in Early Childhood a Student's
Guide to Theory and Practice. London \& New York: Routledge Falmer

Dirjen PAUD (2012) Pedoman Pendidikan Karakter pada Pendidikan Anak Usia Dini, Jakarta: Dirjen PAUD

Dockett, S. and Fleer, M. (2002). Play and Pedagogy in Early Childhood: Bending the Rules. Sydney: Thomson.

Fine, C., \&Thornbury, M. (2006) ICT: play and exploration.ICT in the Early Years. 21-36. New York: Mc Graw Hill

Hayes, M. (2006) Introduction: teaching for tomorrow.ICT in the Early Years.1-5.New York: Mc Graw Hill

Howard R.W., Berkowitz M. W, Schaeffer E. F. (2004) Politics of character education. Educational Policy, 18 (1).188-215.

Jusoff, K., and Sahimi, N., N. (2009) Television and media literacy in young children: Issues and effects in early childhood. International Education Studies, 2 (3).151-157.

Lewis, K. (2016) Helping Mixed Heritage Children Develop 'Character and Resilience' in Schools. Improving Schools.1-15.

Lickona,T. (1989). Educating for Character: How Our Schools can Teach Respect and Responsibility. New York: Bantam.

Malik, R. S. \&Hamied, F. A. (2016) Research Methods: a Guide for First Time Researchers. Bandung: UPI Press

Robertson, J., \& Howells, C. (2008) Computer Game Design: Opportunities for Successful Learning, Computers and Education, 50 (2). 559-578.

Roumell, E., A. \&Salajan, F., D. (2016) The evolution of U.S. e-learning policy: A content analysis of the national education technology plans. Educational Policy, 30(2).365-397.

Silawati, E., \& Rachmania, S. (2014). Gadget : what and how? Indonesian children's perspectives on gadgets.A paper presented at the $2^{\text {th }}$ International Conference on Early Childhood 2014. A Proceeding.

Suyanto, Slamet (2005) Dasar-Dasar Pendidikan Anak Usia Dini. Yogyakarta: Hikayat Publising

Van Eck, R. (2006) Digital game-learning: It's not just the digital natives who are restless.Educause Review, 41 (12). 17-30 